\title{
COLLINEAR SUPPRESSION IN TEXTURE SEGMENTATION FOR TEMPORALLY MODULATED STIMULI
}

\author{
L. Zariņa, S. Fomins \\ ${ }^{1}$ Department of Optometry and Vision Science, University of Latvia, \\ 8 Kengaraga Str., Riga, LV-1063, LATVIA
}

\begin{abstract}
Collinear stimuli facilitate the neural signal in the case of Gabor's stimuli when a low-contrast stimulus inside the receptive field is flanked by higher contrast collinear elements located in surrounding regions of the visual space. Our previous studies pointed to the contextual modulation in the case of the textured stimuli. Collinear suppression was observed in $63 \%$ of the responses. In the current research we used Gabor's primitives for building the circular texture objects of vertical and diagonal orientation to be recognized on the horizontally-oriented background in the presence of collinear and orthogonal peripheral stimuli. The two-alternative forced choice (2AFC) psychophysical method with constant stimuli was used to gather the responses of the subjects which choose between left or right position of diagonallyoriented stimuli. The experimental stimuli consisted of two circularly shaped objects presented in visual angle of 2.76 degrees. The expositions of the stimuli varied from 13.3 to $93.3 \mathrm{~ms}$ arbitrarily. Visual stimuli were presented with a CRS Visage stimulus generator and shown on a CRT monitor of $75 \mathrm{~Hz}$ refresh rate. Our new findings support the concept of suppressing the target stimuli of the same orientation in the presence of a peripheral collinear stimulation.
\end{abstract}

Key words: texture segmentation, contextual modulation, collinear suppression, temporal stimuli.

\section{INTRODUCTION}

In a typical texture segmentation task, a small region of uniform orientation is segregated from a surrounding region of a different orientation [1]. The task becomes more difficult if textures are shown as temporally modulated stimuli.

The receptive field of a neuron in visual cortex is the part of the visual field from which action potential responses can be elicited by presenting a stimulus. The presence of surround stimuli typically results in suppression of the response [2]. Depending on the nature of surround stimuli, this suppression can be reduced or sometimes can even revert to facilitation. One of the forms of suppression that was isolated in the primary visual cortex of cats and monkeys is "surround suppression," in which the mask (a noisy chaotically oriented background) has the orientation preferred by the neuron but is presented outside the receptive field. In recent studies $[3,4]$ it has been shown that the same mechanism of suppression seen in neurons of cats and monkeys is present in human vision.

The purpose of our experiments was to verify if collinear suppression noticed in our previous studies is still present with increasing number of trials. Another intent was to determine if collinear and orthogonal peripheral stimuli alter the recognition of textures for temporally modulated stimuli. The black-white Gabor primitives were used to build circular textures. 


\subsection{Subjects}

\section{EXPERIMENTAL}

Three subjects with normal or corrected-to-normal vision took part in the experiment. All tasks were performed binocularly.

\subsection{Materials and methods}

All measurements were taken with psychophysical two-alternative forced choice (2AFC) method [5], in which the test target appears at one of two locations to the right or to the left of the fixation point. The experimental stimuli were made as two oriented circularly-shaped objects, each consisting of 32 Gabor's primitives. In turn, each Gabor's primitive consisted of 1.5 cycles and was presented within 0.46 degrees of visual angle.

Each circular object was presented within 2.76 degrees of visual angle. The stimuli were presented as temporally modulated in seven different durations from 13.3 to $93.3 \mathrm{~ms}$. Each duration was followed by masking, with a $3000 \mathrm{~ms}$ mask made as the randomly placed Gabor primitives of different orientations.

Black-white temporally altered textures were shown on the horizontallyoriented background, where one of the two objects contained Gabor's primitives with an oblique direction whereas the other was oriented vertically. The subjects had to detect the object with oblique Gabor's primitives as soon as possible.

To perform three psychometrical functions each subject had, using different stimuli, to detect:

1. Only two central circular objects, no peripheral context.

2. Collinear peripheral stimuli added to central objects.

3. Orthogonal peripheral stimuli added to central objects. Fig. 1.

The sample in which orthogonal peripheral stimuli were added is shown in

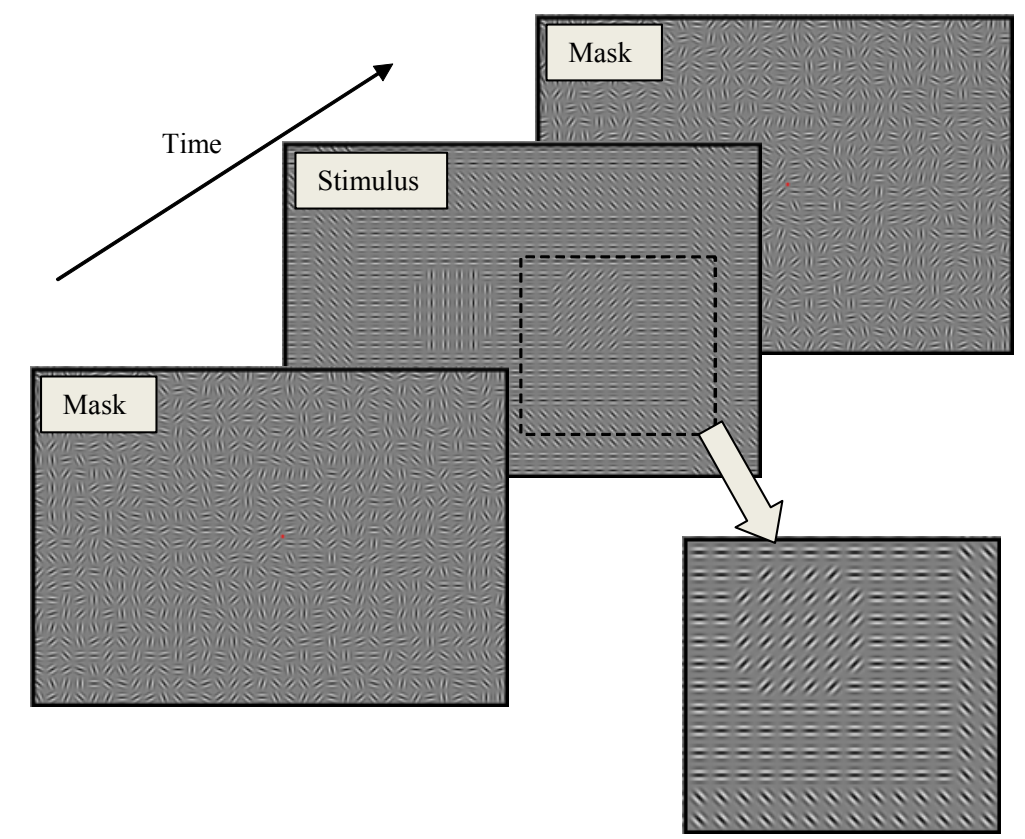

Fig. 1. A stimulus sample: central diagonally-oriented stimulus and peripheral stimulus are orthogonal. 
All items were presented on grey background with a luminance of $67.6 \mathrm{~cd} / \mathrm{m}^{2}$. The Michelson contrast for the black-white Gabor primitives was $94 \%$. The luminance was determined with a KONICA MINOLTA CS-100A chromameter.

Each subject completed 60 trials for each of the seven test durations in three different tasks. The target orientation, the duration order, and the target location were randomized.

Visual stimuli were presented with a CRS Visage stimulus generator on the CRT monitor of $75 \mathrm{~Hz}$ refresh rate.

\section{RESULTS AND DISCUSSION}

In our previous texture segmentation studies [6] it was noticed that the rate of correct answers decreases (i.e. suppression takes place) at medium stimulus durations in $63 \%$ of measurements. In the preset study we increased the number of trials from 10 to 60 for each test duration. To demonstrate the ratio $\mathrm{Y} /(\mathrm{Y}+\mathrm{N})$ vs. stimulus duration in psychometrical function ( $\mathrm{Y}$ - correct responses, $\mathrm{N}$ - incorrect responses) the mean value of 60 trials was used. The obtained psychometrical functions differ between the subjects but in some cases suppression was preserved. In Fig. 2 for subject R.P. less correct answers $(\mathrm{Y} /(\mathrm{Y}+\mathrm{N}))$ at a middle stimulus time are seen for all three psychometrical functions. In the case of collinear stimuli a decreased number of correct answers is at about $53 \mathrm{~ms}$ stimulation time, while for orthogonal and no-context stimuli it is at $40 \mathrm{~ms}$. For subject S.F. (see Fig. 3) a weaker suppression is observed for collinear and orthogonal stimuli. Subject L.Z. (see Fig. 4) does not show any decrease at middle stimulation times.

In some way, a similar suppression effect was observed in Polat et al studies [7], where the variable parameter was stimuli contrast. The response to stimuli presented within the receptive field can be facilitated or suppressed by other stimuli falling outside the receptive field. When presented in isolation, stimuli outside the receptive field fail to activate the cell. Whether this interaction is facilitative or suppressive depends on the relative orientation of pattern elements inside and outside the receptive field. Polat et al showed that neuronal facilitation preferentially occurs when a near-threshold stimulus inside the receptive field is flanked by

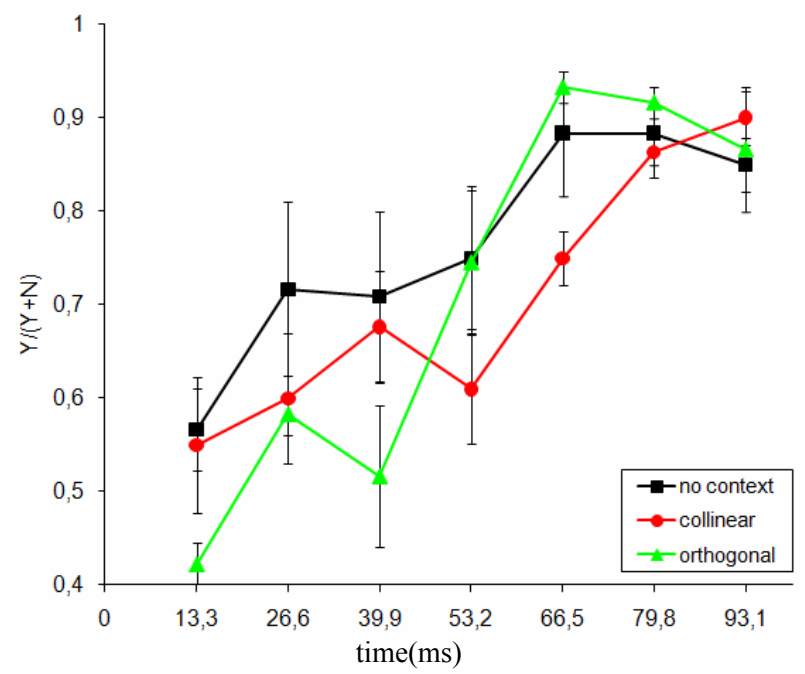

Fig. 2. Psychometrical function for subject R.P. 


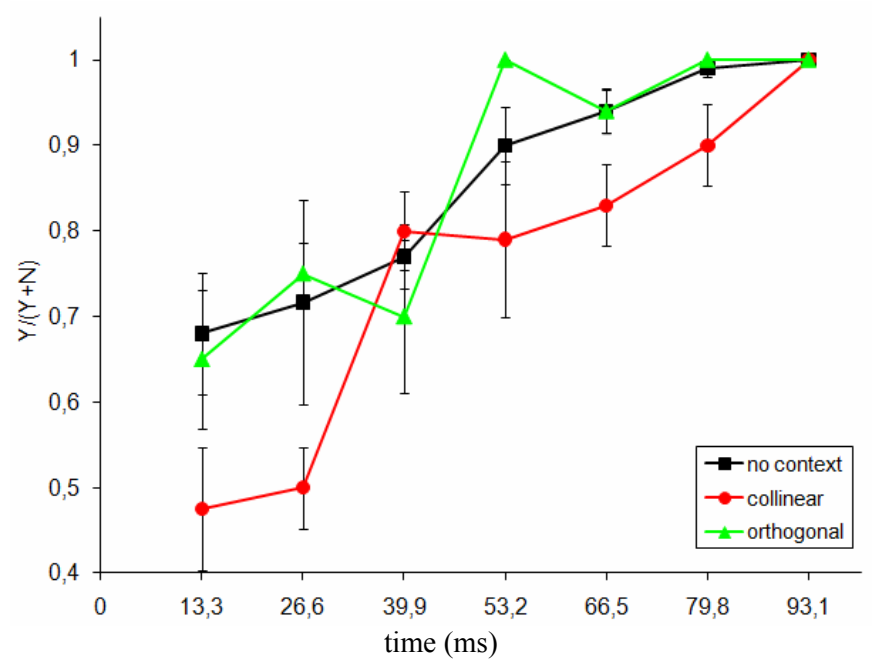

Fig. 3. Psychometrical function for subject S.F.

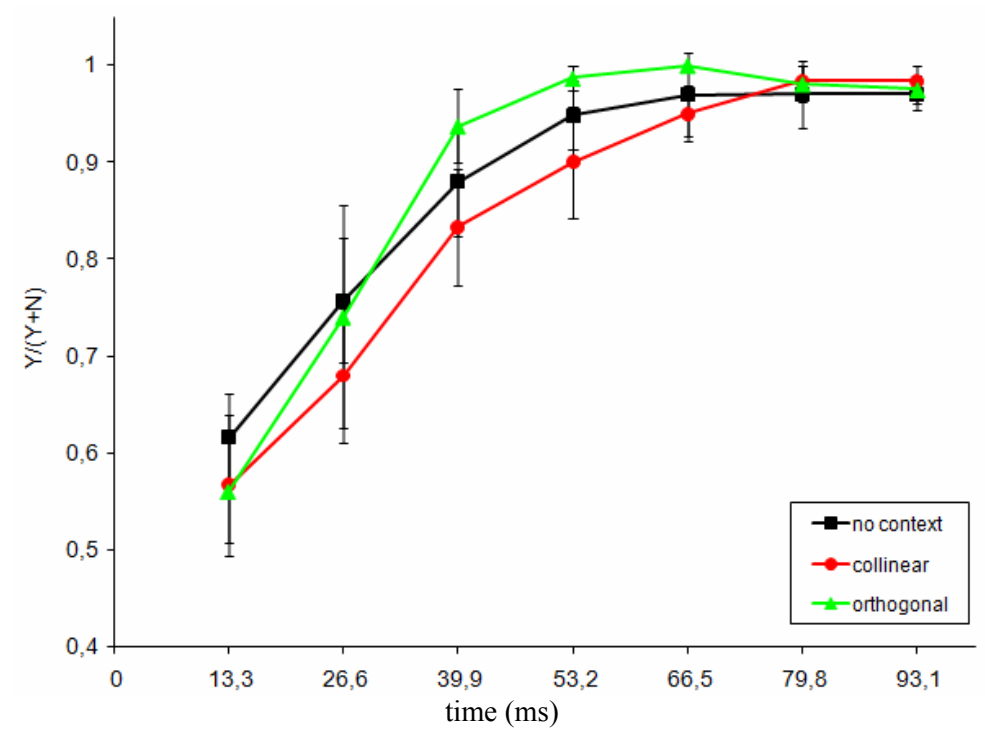

Fig. 4. Psychometrical function for subject L.Z.

higher-contrast collinear elements located in surrounding regions of visual space. Collinear flanks and orthogonally oriented flanks, however, both act to reduce the response to high-contrast stimuli presented within the receptive field [7].

Another purpose of our experiment was to determine whether peripheral stimuli create the effect in contextual modulation. Each individual's three psychometrical functions - measurement with no context (no peripheral stimuli), measurement with collinear peripheral and with orthogonal peripheral stimuli were compared. For this comparison we used another cross-section of the socalled "collinear suppression". For all subjects increase in the number of correct answers is slower for measurements with collinear peripheral stimuli. A suppression effect at smaller stimulus durations can be noticed also in the case of orthogonal peripheral stimulation, but no effect or even opposite facilitation effect occurs at larger durations. For subject R.P. significant difference between measu- 
rements with collinear peripheral stimuli and those with orthogonal peripheral stimuli was noticed in the interval from 53.2 to $79.8 \mathrm{~ms}$. For subject S.F. the same difference was noticed in two intervals: from 13.3 to $26.6 \mathrm{~ms}$ and from 53.2 to $93.1 \mathrm{~ms}$. For subject L.Z. difference between the psychometrical functions for collinear and orthogonal stimuli is not significant.

Primary visual cortex V1 is an anatomical structure that is strongly associated with simple texture segmentation tasks [8]. One of the possible explanations for contextual modulation in the texture segmentation experiments could be the existence of specific anatomical connections in cortex V1. Horizontal connections within this cortex spread over much larger distances than the size of receptive fields would necessitate [2].

There are previous texture segmentation studies where various achromatic stimuli have been used [1, 8-10], but it is little known how the texture segmentation process is affected by coloured stimuli. In our further studies to be devoted to comparison of achromatic and opponent colours it is desirable to demonstrate contribution of different visual pathways to the texture segmentation and the contextual modulation process.

\section{CONCLUSIONS}

The rate of correct answers can be decreased (suppression) at middle stimulation times $(66.5 \mathrm{~ms})$ in the texture segmentation task for temporally modulated stimuli. No correlation has been found between the suppression appearance and the stimulus context.

The contextual modulation in texture segmentation is strongly associated with the collinear peripheral stimulation. No effect (suppression or facilitation) occurs in the case of orthogonal peripheral stimulation, but only suppression effect is observed in the context of collinear peripheral stimulation.

\section{REFERENCES}

1. Scialfa, C.T., \& Hamaluk, E. (2001). Aging, Texture Segmentation, and Exposure Duration: Evidence for a Deficit is Preattentive Processing. Experimental Aging Research, 27, 123-135.

2. Chalupa, L.M., \& Werner, J.S. (2004). The Visual Neurosciences. Vol. 1. Cambridge, (MA), London, England: A Bradford Book (the MIT Press).

3. Petrov, Y., Carandini, M., \& McKee, S. (2005). Two Distinct Mechanisms of Suppression in Human Vision. J. Neurosci., 25(38), 8704-8707.

4. Carandini, M. (2004). Receptive fields and suppressive fields in the early visual system. The cognitive neurosciences, Ed.3, 313-326. Cambridge, MA: MIT Press.

5. Norton, T.T., Corliss, D.A., \& Bailey, J.E. (2002). The Psychophysical Measurement of Visual Function. USA: Butterworth Heinemann

6. Fomins, S., \& Zarina, L. (2009). Segmentation of instant isoluminant chromatic textures. Perception, 38. ECVP Supplement, p.54

7. Polat, U., Mizobe, K., Pettet, M.W., Kasamatsu, T., \& Norcia, A.M. (1998). Collinear stimuli regulate visual responses depending on cell's contrast threshold. Nature, 391, 580-584

8. Chalupa, L.M., \& Werner, J.S. (2004). The Visual Neurosciences. Vol. 2. Cambridge, Massachusetts, London, England: A Bradford Book (the MIT Press).

9. $\mathrm{Li}, \mathrm{Z}$. (1999). Contextual influences in V1 as a basis for pop out and asymmetry in visual search. Proc. Natl. Acad. Sci. USA, Vol. 96, 10530-10535. 
10. Li, Z. (1999). Primary visual cortex as a saliency network for pre-attentive segmentation. In: 3rd Annual Vision Research Conference Pre-attentive and Attentive Mechanisms in Vision, Florida, USA, May 7-8.

\title{
KOLINEĀRA SUPRESIJATEKSTŪRU SEGMENTĀCIJAS EKSPERIMENTOS, IZMANTOJOT LAIKĀ MAINĪGUS STIMULUS
}

\author{
L. Zariņa, S. Fomins
}

Kopsavilkums

Ja receptīvajā laukā esošu zema kontrasta Gabora stimulu apņem kolineāri augstāka kontrasta stimuli, kas izvietojas ārpus receptīvā lauka robežām, tiek novērota kolineāra pastiprināšana. Palielinot centrālā stimula kontrastu, pastiprināšana var pārvērsties supresējošā darbībā (Polat et al, 1998). Mūsu iepriekšējos tekstūru segmentācijas pētījumos tika novērotas no konteksta atkarīgas izmainas $63 \%$ mērījumu (Fomins et al, 2009). Šajā pētījumā vertikāli un diagonāli vērstas tekstūras tika veidotas, izmantojot Gabora stimulus. Tekstūras tika izvietotas uz horizontāli vērsta fona, turklāt centrāliem stimuliem tika pievienoti kolineāri un ortogonāli stimuli perifērijā. Subjektu atbildes tika iegūtas ar 2AFC konstanto stimulu psihofizikālo metodi. Subjektam bija jāizvēlas pa diagonāli vērsto stimulu labajā vai kreisajā pusē. Eksperimenta stimuli tika rādīti 2.76 grādos no redzes leņķa. Stimulu rādīšanas ilgums tika nejauši mainīts intervālā no 13.3 līdz 93.3 ms. Eksperiments tika demonstrēts ar CRS Visage stimulu generatoru uz CRT tipa monitora ar $75 \mathrm{~Hz}$ frekvenci. Pētījumā secināts, ka laikā mainīgu stimulu tekstūru segmentācijas eksperimentos var samazināties pareizo atbilžu skaits (supresija) pie vidējiem stimula rādīšanas ilguma laikiem. Tekstūru segmentācijas kontekstuālā modulācija saistīta ar kolineāru stimulāciju perifērijā. Izmantojot ortogonālu perifērijas stimulāciju, var novērot gan supresiju, gan atbildes pastiprināšanu, gan neizmainītu atbildi, salīdzinot ar mērījumu bez perifērijas stimulācijas. 